African Crop Science Journal by African Crop Science Society is licensed under a Creative Commons Attribution 3.0 Uganda License. Based on a work at www.ajol.info/ and www.bioline.org.br/cs DOI: http://dx.doi.org/10.4314/acsj.v24i1.7

\title{
GENE EFFECTS FOR RESISTANCE TO GROUNDNUT ROSSETTE DISEASE IN EXOTIC VALENCIA GROUNDNUTS
}

R.G. NALUGO, W. WAMBI ${ }^{1}$, J.M. SEBBULIBA ${ }^{2}$, D.K. OKELLO ${ }^{4}$ and N. PUPPALA ${ }^{3}$

National Agricultural Research Organization, Rwebitaba Zonal Agricultural Research and Development Institute, P. O. Box 96, Fortportal, Uganda

${ }^{1}$ National Agricultural Research Organization, Bulindi Zonal Agricultural Research and Development Institute, P. O. Box 101 Hoima, Uganda

${ }^{2}$ Department of Agricultural Production, School of Agricultural Sciences, Makerere University, P. O. Box 7062, Kampala, Uganda

${ }^{3}$ New Mexico State University-Agricultural Science Center at Clovis, 2346 SR 288, Clovis, New Mexico, USA

${ }^{4}$ National Semi-Arid Resources Research Institute, P. O. Box Private Bag Soroti, Uganda Corresponding author: wambiwilber@yahoo.com

(Received 22 March, 2015; accepted 25 February, 2016)

\begin{abstract}
Two exotic Valencia groundnut (Arachis hypogaea L.) breeding lines (NuMex-M $\mathrm{M}_{3}$ and Valencia C) with superior characteristics were introduced by National Legume Improvement Program at the National Semi-Arid Resources Research Institute (NaSARRI), from the United States of America, to broaden the Valencia germplasm base in Uganda. The materials were evaluated for biotic and abiotic stresses, but succumbed to groundnut rosette disease (GRD). For these superior lines to find utility in Uganda, they need further improvement by introducing resistance genes to GRD. A study was conducted at NaSARRI to determine nature of gene action controlling resistance to GRD, using the Exotic Valencia groundnut breeding materials. Six generations that included $\mathrm{F}_{1}, \mathrm{~F}_{2}$, $\mathrm{BC}_{1} \mathrm{P}_{1}$ and $\mathrm{BC}_{1} \mathrm{P}_{2}$ populations, together with their parents $\left(\mathrm{P}_{1}\right.$ and $\left.\mathrm{P}_{2}\right)$ of each of the six crosses, namely Valencia C $\left(\mathrm{P}_{1}\right) \times$ ICGV-SM $90704\left(\mathrm{P}_{2}\right)$, Valencia C $\left(\mathrm{P}_{1}\right) \times$ ICGV-SM $96801\left(\mathrm{P}_{2}\right)$, Valencia C $\left(\mathrm{P}_{1}\right) \times$ ICGV-SM $99566\left(\mathrm{P}_{2}\right)$, NuMex-M $3\left(\mathrm{P}_{1}\right) \times$ ICGV-SM $90704\left(\mathrm{P}_{2}\right)$, NuMex-M $\times$ ICGV-SM $96801\left(\mathrm{P}_{2}\right)$, and NuMex-M $\mathrm{M}_{3}\left(\mathrm{P}_{1}\right) \times \mathrm{ICGV}_{-}$ SM $99566\left(\mathrm{P}_{2}\right)$, were evaluated for GRD resistance.The study reaveled additive and non-additive gene effects in the control of GRD resistance.Three types of epistatic gene effects, viz. additive $\times$ additive [i], additive $\times$ dominance [j] and dominance $\times$ dominance [1],were exhibited tocontrol GRD resistance. The component dominance $\times$ dominance [1] was more predominant in Valencia $\mathrm{C} \times$ ICGV-SM 96801, NuMex-M $\times$ ICGV-SM 96801, NuMex- $\mathrm{M}_{3} \times$ ICGV-SM 90704, NuMex-M $\times$ ICGV-SM 99566 and Valencia C $\times$ ICGV-SM 99566 crosses. Opposite and significant signs of dominance [d] and dominance $\times$ dominance [1] components indicated the importance of duplicate epitasis in the latter crosses in the control of GRD resistance, which revealed a complex nature of inheritance of GRD resistance.
\end{abstract}

Key Words: Arachis hypogaea, gene effects, GRD resistance

\section{RÉSUMÉ}

Deux nouvelles variétés d'arachide (Arachis hy pogaea L.) de la lignée Valencia (NuMex-M et Valencia C) ayant des traits supérieurs, ont été importées des Etats Unis d'Amériques par le Programme National d'amélioration des légumineuses et introduites à l'Institut Nationale de Recherche sur les Ressources Semi-Arides (NaSARRI), 
dans le but d'élargir la base génétique de la lignée Valencia en Ouganda. Ce matériel génétique a été évalué pour les stress biotiques et abiotiques, mais a succombé à l'attaque par la rosette d'arachide (GRD). Afin que ces lignées supérieures trouvent leur utilité en Ouganda, il faudra les améliorer d'avantage, en y introduisant des genes de résistance au GRD. Une expérimentation a été conduite à NaSARRI afin de determiner l'action des genes controllant la résistance au GRD, en se servant des lignées exotiques du type d'arachide Valencia. Six générations formées de $\mathrm{F}_{1}, \mathrm{~F}_{2}, \mathrm{BC}_{1} \mathrm{P}_{1}$ et $\mathrm{BC}_{1} \mathrm{P}_{2}$ populations, et des parents $\left(\mathrm{P}_{1}\right.$ and $\left.\mathrm{P}_{2}\right)$ de chacun des six croisements, plus précisément, Valencia C $\left(\mathrm{P}_{1}\right) \times \operatorname{ICGV-SM} 90704\left(\mathrm{P}_{2}\right)$, Valencia C $\left(\mathrm{P}_{1}\right) \times \operatorname{ICGV}-\mathrm{SM} 96801\left(\mathrm{P}_{2}\right)$, Valencia C $\left(\mathrm{P}_{1}\right) \times$ ICGV-SM $99566\left(\mathrm{P}_{2}\right)$, NuMex-M $\left(\mathrm{P}_{1}\right) \times$ ICGV-SM $90704\left(\mathrm{P}_{2}\right)$, NuMex-M $\times$ ICGV-SM $96801\left(\mathrm{P}_{2}\right)$, et NuMex-M $\mathrm{M}_{3}\left(\mathrm{P}_{1}\right) \times$ ICGV-SM $99566\left(\mathrm{P}_{2}\right)$, ont été évalué pour leur résistance au GRD. L'étude a révélé des effets additifs et non-additifs des gènes controllant la résistance au GRD. Trois types d'effets epistatiques des gènes, viz. additif $\times$ additif [i], additif $\times$ dominance [j] and dominance $\times$ dominance [1], ont été observés. La composante dominance $\times$ dominance [1] était la plus prédominante chez les croisements Valencia C $\times$ ICGV-SM 96801, NuMex-M $\times$ ICGV-SM 96801, NuMex- M $\times$ ICGV-SM 90704, NuMex-M $\times$ ICGV-SM 99566 et Valencia C $\times$ ICGV-SM 99566. Des signes opposés et significatives des composantes dominance $[d]$ et dominance $\times$ dominance [1] ont montré l'importance de la double épistasie dans les derniers croisements pour la résistance au GRD, indiquant ainsi la nature complexe du mode de transmission de la résistance au GRD.

Mots Clés: Arachis hypogaea, effet des gènes, résistance au GRD

\section{INTRODUCTION}

Development of improved cultivars requires understanding of the nature of gene action governing key traits, such as groundnut rosette disease (GRD) resistance in the germplasm used for breeding. However, there is limited information on the nature and type of gene interactions exististing in groundnuts (Arachis hypogaea L.), particularly for GRD resistance. This information is necessary for planning appropriate breeding and selection strategies (Zhang et al., 2005; Wambi et al., 2014). According to Singh and Oswalt (1991), variation due to dominance effects and their interactions cannot be exploited effectively in groundnut; while additive $\times$ additive epistatic variation is potentially useful, as it can be fixed in homozygous cultivars.

Many workers have reported that additive effects are predominant over non-additive effects in governing GRD resistance (Adamu et al., 2008; Chintu, 2013; Kayondo et al., 2014). According to Wambi et al. (2014), the type of gene effect depends on the genetic background of the parents and variation in environmental conditions in which the populations are evaluated. Many methods, including use of mating designs have been employed in studies of gene effects, but lack capacity to estimate individual interaction effects precisely. The presence or absence of epistasis can be detected by generation mean analysis, which measures epistasis accurately, whether complimentary or duplicate, even with low populations at the digenic level (Keasey and Pooni 1996). The objective of this study was to determine the nature of gene effects controlling GRD resistance to facilitate breeders to design sound breeding program for GRD resistance and, hence developing groundnut genotype with GRD resistance.

\section{MATERIALS AND METHODS}

Study site. The study was conducted at the National Semi-Arid Resources Research Institute (NaSARRI) of the National Agricultural Research Organisation (NARO) in Uganda, a known hot spot for groundnut rosette disease in the country (Okello et al., 2010). NaSARRI is located at $01^{\circ}$ - $3000 \mathrm{~N}$ and $33^{\circ}-3300 \mathrm{E}$ in Serere district and receives mean annual rainfall of 1,000-1,200 mm.

Study materials. Five parents were used in this study (Table 1). Rosette resistant lines: Serenut 6T(ICGV SM 99566), Serenut 2 (ICGV-SM 90704) and Mali (ICGV-SM 96801) were provided by the Groundnut Improvement Program at the NaSARRI. The exotic susceptible Valencia lines; Valencia $\mathrm{C}$ and NuMex-M were provided by the Plant Breeding Department New Mexico State University in USA.

First filial generations $\left(F_{1}\right)$. Valencia $C$ and NuMex- $\mathrm{M}_{3}$ were used as female lines (exotic 
susceptible lines); while ICGV-SM 90704, ICGVSM 96801 and ICGV-SM 99566 were the male local resistant lines. Five seeds from each parent were planted in plastic pots of diameter $45 \mathrm{~cm}$ and height $15 \mathrm{~cm}$, containing loam soils. The parents were grown in a glasshouse and the seedlings were thinned to two. Plants were watered after every two days up to harvest, using one litre of tap water. Staggered planting of parents was done, where male parents were planted 10 days before the female parents, so as to synchronise the flowering. It was also done to ensure continuous availability of flowers for making crosses.

During flowering, the parents were emasculated using a pair of forceps in the morning (6:30 and 8:30 am) and evenings (6:30 and 7:20 $\mathrm{pm}$ ) for 21 days. Pollination was done carefully and manually rubbing the pollen from resistant parents onto the stigma of the susceptible emasculated parents, by hands. The nodes of the flowers that were crossed tagged with a label to enable easy identification of successfully crosses.

Bi-parental mating design was employed, whereby a total of six crosses (Valencia $\mathrm{C} \times \mathrm{ICGV}$ SM 90704, Valencia C $\times$ ICGV-SM 96801, Valencia C $\times$ 99566, NuMex-M $\times$ ICGV-SM 90704, and NuMex-M ${ }_{3} \times$ ICGV-SM 96801 and NuMex-M ${ }_{3} \times$ ICGV-SM 99566) were made. In each cross, 20 flowers were pollinated. Mature pods from each parent and cross were harvested separately, dried, packed in labeled envelops and stored at room temperatures.

Generation of $\mathrm{F}_{1}, \mathrm{~F}_{2}, \mathrm{BC}_{1} \mathrm{P}_{1}$ and $\mathrm{BC}_{1} \mathrm{P}_{2}$ populations. Twenty $F_{1}$ seeds generated above from each cross, together with their respective parents, were planted in plastic pots containing loam soil under a glasshouse at the National SemiArid Resources Research Institute (NaSARRI). The $\mathrm{F}_{1}$ seeds were raised in close proximity with their parents, to support the identification of the successful crosses. During flowering, ten plants were selfed to generate $F_{2}$ seeds; while five plants were backcrossed to susceptible parents, and other five plants backcrossed to resistant parents to generate $\mathrm{BC}_{1} \mathrm{P}_{1}$ and $\mathrm{BC}_{1} \mathrm{P}_{2}$ seeds, respectively. The process of emasculation and pollination to generate $\mathrm{BC}_{1} \mathrm{P}_{1}$ and $\mathrm{BC}_{1} \mathrm{P}_{2}$ seeds, was done as 
described for generation $F_{1 s}$ above. The parents were also crossed to generate more $\mathrm{F}_{1}$ seeds as described above.

Study evaluation. The six generations $\left(\mathrm{P}_{1}, \mathrm{P}_{2}, \mathrm{~F}_{1}\right.$, $\mathrm{F}_{2}, \mathrm{BC}_{1} \mathrm{P}_{1}$ and $\left.\mathrm{BC}_{1} \mathrm{P} 2\right)$ of each cross were evaluated in the field at NaSARRI, in a randomised complete block design (RCBD). The study materials were planted in a six row plot, of $3 \mathrm{~m}$ length at spacing of $45 \mathrm{~cm} \times 15 \mathrm{~cm}$, in three replications.

The infector row technique was used to build up disease pressure on the experimental materials that were naturally inoculated. Acholi white, a highly rosette susceptible local variety, was used as the infector line, and was planted in a single row between every two rows of test materials. The infector rows were planted 14 days before the test materials.

Data collection and analysis. Groundnut rossette disease severity data were scored at 115 days after planting, using a 1-9 scale adopted from the Legume Improvement Program of the National Semi-Arid Resources Research Institute (NaSARRI). The disease scores on individual plants of the six generations $\left(\mathrm{P}_{1}, \mathrm{P}_{2}, \mathrm{~F}_{1}, \mathrm{~F}_{2}\right.$, $\mathrm{BC}_{1} \mathrm{P}_{1}$ and $\mathrm{BC}_{1} \mathrm{P}_{2}$ ) from each of the six crosses (Valencia C × ICGV-SM 90704, Valencia C × ICGV-SM 96801, Valencia C × ICGV-SM 99566, NuMex-M $\times$ ICGV-SM 90704, NuMex-M $\times$ ICGV-SM 96801 and NuMex-M $\times$ ICGV-SM 99566) were taken. The generation means and variances from individual plant data were calculated for every generation separately. The data were subjected to individual scaling tests, viz. A, B and C to detect the presence of epistasis following Marther and Jinks (1982) method. The gene effects were calculated following the six parameter model as described by Mather and Jinks (1971). The average value between parents $(\mathrm{m})$, additive effect $[a]$, dominance effects $[d]$, additive $\times$ additive $[i]$, additive $\times$ dominance $[j]$ and dominance $\times$ dominance effects $[l]$ genetic parameters were estimated.

\section{RESULTS}

The results of the scaling tests along with their standard error and t-test are presented in Table 2. Atleast 1 of the 3 ( A, B and C) scaling tests was significantly different from zero (Table 2), thus revealing significance of non-allelic interaction in control of GRD resistance; and therefore, interacting terms were computed. Results on gene effects are presented in (Table 3). There was a significant contribution of additive gene effects [a] in controlling resistance to GRD in all the crosses, except for NuMex-M $\times$ ICGV-SM 96801 (Table 3). Dominance [d] gene effects were significant in all the six crosses, except in Valencia $\mathrm{C} \times \mathrm{ICGV}-\mathrm{SM} 99566$ and Valencia C $\times$ ICGV-SM 90704 crosses (Table 3 ). The magnitude of dominance gene effects was generally larger than that of additive gene effect in all crosses, except Valencia C × ICGV-SM 99566.

All epistatic type effects were not significant for Valencia $\mathrm{C} \times \mathrm{ICGV}$-SM 90704 cross. Only dominance $\times$ dominance (l) gene effects were siginficant in Valencia $\mathrm{C} \times$ ICGV-SM 96801,NuMex-M $\times$ ICGV-SM 96801,NuMex-M $\times$ ICGV-SM 90704 and NuMex-M $\times$ ICGV-SM 99566 crosses.Cross Valencia C $\times$ ICGV-SM 99566 had all the three types of epistatic effects significant, such as additive $\times$ additive [i], additive $\times$ dominance [j] anddominance $\times$ dominance [1] (Table 3 ). The magnitude of dominance $x$ dominance interaction [1] effects was generally larger than other genetic interactions, except for Valencia C × ICGV-SM 90704 cross.

\section{DISCUSSION}

At least one of the three scaling tests was significant in each cross (Table 2), implying that additive-dominance model was inadequate to explain the inheritance of GRD resistance for all the six crosses. Therefore, epistatic interaction and maternal effects could be involved in the inheritance of GRD resistance. The presence of significant additive gene effects [a] (Table 3) implied that genetic improvement of resistance to GRD is possible through selection methods. The dominance gene effects [d] were significant and greater in magnitude than the additive effect [a] in all crosses, except Valencia $\mathrm{C} \times \mathrm{ICGV}-\mathrm{SM}$ 99,566 (Table 3). This suggests a predominant role of dominance gene action in controlling GRD resistance. The results are comparable with those of Olurunju et al. (1992) and Akpan and Olurunju (2009), which revealed that the inheritance of 
TABLE 2. Scaling test estimates with their standard errors and $t$-test for six crosses

\begin{tabular}{|c|c|c|c|c|c|c|c|c|c|c|c|c|}
\hline \multirow[t]{2}{*}{ Scale } & \multicolumn{2}{|c|}{$\begin{array}{c}\text { Valencia C } \\
\text { x ICGV-SM } 99566\end{array}$} & \multicolumn{2}{|c|}{$\begin{array}{c}\text { Valencia C } \\
\text { x ICGV-SM } 90704\end{array}$} & \multicolumn{2}{|c|}{$\begin{array}{c}\text { Valencia C } \\
\text { x ICGV-SM } 96801\end{array}$} & \multicolumn{2}{|c|}{$\begin{array}{c}\text { NuMex-M }_{3} \\
\text { x ICGV-SM } 99566\end{array}$} & \multicolumn{2}{|c|}{$\begin{array}{c}\text { NuMex-M } \\
\text { x ICGV-SM } 90704\end{array}$} & \multicolumn{2}{|c|}{$\begin{array}{c}\text { NuMex-M } \\
\text { x ICGV-SM } 96801\end{array}$} \\
\hline & Value observed & t val & Value observed & $\mathrm{t}$ val & Value observed & t val & Value observed & t val & Value observed & t val & Value observed & t val \\
\hline$A$ & $3.9 \pm 1.6 \mathrm{~ns}$ & 1.57 & $-3.7^{\star} \pm 1.45$ & -1.72 & $7^{*} \pm 0.75$ & 15.59 & $6.67^{\star} \pm 0.59$ & 24.98 & $-0.92^{\star} \pm 0.95$ & -5.12 & $-6.16^{*} \pm 0.6$ & -14.4 \\
\hline B & $1.3 \pm 0.7 \mathrm{~ns}$ & 0.39 & $-5.3 \pm 1.89 \mathrm{~ns}$ & 0.67 & $9.6 \pm 1.7 \mathrm{~ns}$ & 0.31 & $11.5 \pm 2.34 \mathrm{~ns}$ & 0.475 & $0.57^{*} \pm 0.6 \mathrm{~ns}$ & 0.1 & $3.7 \pm 0.57 \mathrm{~ns}$ & 0.707 \\
\hline C & $7.7^{*} \pm 1.8$ & 2.27 & $8 \pm 4.77 \mathrm{~ns}$ & 0.35 & $11.67 \pm 3.9 \mathrm{~ns}$ & 0.73 & $-5.17^{\star} \pm 1.18$ & -3.73 & $3.93^{*} \pm 3.9 \mathrm{~ns}$ & 1.01 & $7.16 \pm 7.2 \mathrm{~ns}$ & 0.138 \\
\hline
\end{tabular}

$A=$ scaling test $A, B=$ scaling test $B$ and $C=$ scaling test $C$, and $t=$ calculated $t-$ values, ${ }^{*}=$ significant $5 \%, n s=$ Not significant

TABLE 3. Genetic parameters for GRD disease score for six crosses

\begin{tabular}{|c|c|c|c|c|c|c|}
\hline G E & $\begin{array}{c}\text { Valencia C } \\
\times \text { ICGV-SM } 99566\end{array}$ & $\begin{array}{c}\text { Valencia C } \\
\times \quad \text { ICGV-SM } 96801\end{array}$ & $\begin{array}{c}\text { Valencia C } \\
\times \text { ICGV-SM } 90704\end{array}$ & $\begin{array}{l}\text { NuMex-M }_{3} \\
\times \text { ICGV-SM } 96801\end{array}$ & $\begin{array}{c}\text { NuMex-M }_{3} \\
\times \text { ICGV-SM } 90704\end{array}$ & $\begin{array}{c}\text { NuMex-M } \\
\times \text { ICGV-SM } 99566\end{array}$ \\
\hline [m] & $6.7 \pm 2.8$ & $1.3 \pm 4$ & $11.2 \pm 5.4$ & $1.2 \pm 8.1$ & $19.2 \pm 4.1$ & $18.1 \pm 0.2$ \\
\hline [a] & $3.2^{*} \pm 0.2$ & $3.17^{*} \pm 0.36$ & $3.0^{*} \pm 0.26$ & $1.8 \pm 0.85$ & $3.2^{*} \pm 0.2$ & $3.4^{*} \pm 0.2$ \\
\hline [d] & $2.5 \pm 0.6$ & $22.2^{*} \pm 0.6$ & $13.9 \pm 0.4$ & $22.2^{*} \pm 0.8$ & $31.7^{*} \pm 0.6$ & $61^{*} \pm 1.2$ \\
\hline [i] & $-2.3^{*} \pm 2.8$ & $5 \pm 3.96$ & $-6.3 \pm 5.4$ & $5.9 \pm 8.7$ & $-14.7 \pm 4$ & $23.3 \pm 2.5$ \\
\hline [j] & $2.7^{\star} \pm 2.7$ & $-2.7 \pm 1.8$ & $-9 \pm 2.69$ & $-25 \pm 3.7$ & $-10.3 \pm 1.3$ & $-4.8 \pm 2.4$ \\
\hline$[I]$ & $-2.9^{\star} \pm 4.8$ & $-21.6^{*} \pm 4.8$ & $-4.6 \pm 7.2$ & $-19.2^{*} \pm 10$ & $-13.6^{*} \pm 4.7$ & $-41^{*} \pm 4.8$ \\
\hline
\end{tabular}

$[\mathrm{m}]=$ representsmean; $[a]=$ additive; $[d]=$ dominance; []$=$ additive $\times$ additive; []$]=$ additive $\times$ dominance; and $[l]=$ dominance $\times$ dominanceeffects 
resistance to rosette disease was governed by dominant genes.

For Valencia C $\times$ ICGV-SM 90704 cross, additive gene effects were the most important for GRD disease score(Table 3); while other effects were less important, indicating that selection in early generations of segregating populations of this cross might be effective for GRD resistance. The results are comparable with those of Chintu (2013) and Adamu et al. (2008), which revealed predominance of additive gene actions incontrol of GRD resistance. However, Wambi et al. (2014) reported that effective selection in early generations of segregating materials can be accomplished only when additive genetic effects are substantial and heritability is high. Therefore, in the Valencia C $\times$ ICGV-SM 90704cross, selection in early generations of segregating materials may be effective if heritability is high.

The study reaveled three types of epistatic gene effects, viz.additive $\times$ additive [i], additive $\times$ dominance [j] and dominance $\times$ dominance [1] (Table 3), in the control of GRD resistance.This is contrary to findings by many workers, who reported predominace of additive (Adamu et al., 2008; Chintu, 2013; Kayondo et al., 2014) and dominace (Olurunju et al., 1992; Akpan and Olurunju, 2009) gene effects. Such variations could be due to the genetic background of the parents, and variation in environmental conditions in which the populations were evaluated. Wambi et al. (2014) also concluded that the type of gene effect depends on the genetic background of the parents and variation in environmental conditions in which the populations are evaluated. Therefore, knowledge of gene effects of a given breeding material in a particular environment is paramount for successful genetic improvement of any trait.

For interaction components, the dominance $x$ dominance [1] effects were more prominent than additive $\times$ additive [i] and additive $\times$ dominance [j], in Valencia C× ICGV-SM 96801, NuMex-M $\times$ ICGV-SM 96801, NuMex- M $\times$ ICGV-SM 90704 , NuMex-M $\times$ ICGV-SM 99566 and Valencia C $\times$ ICGV-SM 99566 crosses (Table 3). In addition, the crosses exhibited opposite and significant signs of dominance [d] and dominance $x$ dominance [1] effects, underscoring the importance of duplicate epitasis in almost all the later crosses for GRD resistance. This reveals the complex nature of inheritance of GDR resistance, which would hinder genetic improvement of the trait through simple selection methods. In this situation, breeding methods such as reciprocal recurrent selection is recommended for effective utilisation of both additive and non-additive gene effects, simultaneously. According to Shoba et al. (2010), the duplicate epistasis observed, hinders the rapid improvement of a trait by selection. Delaying the selection to later generations, when additive gene effects are fixed, and use of recurrent selection could be the appropriate breeding strategies for improving such a trait.Selection in later generations and maintenance of large populations prior to selection may provide the maximum opportunity for advantageous combinations of genes to occur. For traits controlled by additive and nonadditive gene effect, Kearsey and Pooni (1996) and Wambi et al. (2014) recommended that selection should be done in later generations when additive effects are fixed.

In Valencia $\mathrm{C} \times \mathrm{ICGV}-\mathrm{SM} 99566$ cross additive [a] $(3.2 * \pm 0.2)$, additive $\times$ additive [i] $(-2.3 * \pm 2.8)$ additive $\times$ dominance $[\mathrm{j}](2.7 * \pm 2.7)$ and dominance $x$ dominance $[1](-2.9 * \pm 4.8)$ were significant (Table $3)$. Presence of significant additive and additive $\times$ additive [i] revealed potentially useful variation which can be fixed easily. According to Singh and Oswalt (1991), variation due to additive $\times$ additive epistatic interactions is potentially useful, as it can be fixed in homozygous cultivars; while dominance effects and their interactions cannot be exploited effectively in groundnut. The breeding method that exploits both additive and non-additive gene effects such as recurrent selection (Singh and Oswalt, 1991; Kearsey and Pooni, 1996; Nidagundi et al., 2012; Janila et al., 2013; Wambi et al., 2014), reciprocal recurrent selection (Janila et al., 2013) and biparental mating (Dabholkar, 1992) could be suitable for improving traits controlled by both additive and nonadditive effects.

\section{CONCLUSION}

The estimates of gene effects obtained vary depending on the parental backgrounds used in making cross. It is apparent that the inheritance 
of GRD in all the crosses is under the control of additive and non-additive gene effects, coupled with duplicate type of epitasis. The duplicate epitasis reveals a complex nature of inheritance GRD resistance. Therefore, breeding strategies should be designed accordingly to achieve desired results. Delaying selection to later generations when additive gene effects are fixed, and use of recurrent selection could be the appropriate breeding strategies for the improvement of groundnut for rosette resistance.

\section{ACKNOWLEDGEMENT}

This study was supported by the United States Agency for International Development (USAID) under the Peanut Collaborative Research Support Programme (Peanut CRSP) grant ECG-A-00-070001-00. We acknowledge the Legume Improvement Program, and National Semi-Arid Resources Research Institute (NaSARRI) of National Agricultural Research Organisation (NARO) for providing germplasm, glasshouse for hybridisation operations and field for evaluation of breeding materials.

\section{REFERENCES}

Adamu, A.K., Olorunju, P.E., Ado, S.G. and Alabi, S.O. 2008. General and specific combining ability estimates for rosette resistance, early maturity and other agronomic traits in groundnut (Arachis hypogaea L.). International Journal of Pure and Applied Sciences 2:33-41.

Akpan, G.I. and Olorunju, P.E. 2009. Yield stability and resistance to leaf spot diseases and rosette in groundnut. Czech Journal of Genetics and Plant Breeding 45 (1): 18-25.

Chintu, J.M.M. 2013. Breeding groundnut for resistance to rosette disease and its aphid vector, Aphis craccivoraKoch in Malawi. $\mathrm{PhD}$ Thesis, University of KwaZulu-Natal. Pietermaritzburg, Republic of South Africa.

Dabholkar, A.R. 1992. Elements of Biometrical Genetics. Concept Publishing Company, New Delhi 110059, South Asia. pp. 38-165.

Janila, P., Ramaiah,V., Rathore, A., Upakula, A., Reddy, R.K., Waliyar, F. and Nigam, S.N. 2013. Genetic analysis of resistance to late leaf spot in inter-specific groundnuts. Euphytica. ICRISAT. pp. 1-11.
Kayondo, S.I, Rubaihayo, P.R., Ntare1, B.R., Gibson, P.T., Edema, R., Ozimati, A. and Okello, D.K. 2014. Genetics of resistance to groundnut rosette virus disease. African Crop Science Journal 22:21-29.

Kearsey, J.M. and Pooni, S.H. 1996. The genetic Analysis of quantitative Traits. $1^{\text {st }} \mathrm{Edn}$. Chapman and Hall, London, UK.

Mather, K. and Jinks, J.L. 1982. Biometrical genetics.Cornel University Press.Thaca. N.Y., USA.

Mather, K. and Jinks, J.L. 1971. Biometrical Genetics: The study of continuous variation. Chapman \& Hall, London, UK.

Nidagundi, J.M., Patil, S.S., Salimath, P.M., Kajjidoni, S.T., Patil, B. C. and Hegde, M. G. 2012. Genetic analysis of seed cotton yield and its component traits in Gossypium hirsutum L. Karnataka Journal of Agricultural Science 25: 260-261.

Okello, D. K., Biruma, M. and Deom, C. M. 2010. Overview of groundnuts research in Uganda: Past, present and future. African Journal of Biotechnology 9:6448-6459.

Olorunju, P.E., Kuhn ,C.W., Demski, J.W., Misari, S.M. and Ansa O.A. 1992. Inheritance of resistance in peanut to mixed infections of Groundnut Rosette Virus (GRV) and Groundnut Rosette Assistor Virus and a single infection of GRV. Plant Disease 76:95100.

Shoba, D., Manivannan, N. and Vindhiyavarman, P. 2010. Gene effects of pod yield and its components in three crosses of groundnut (Arachis hypogaea L.). Electronic Journal of Plant Breeding 1:1415-1419.

Singh, F. and Oswalt, D.L. 1991. Genetics and breeding of groundnut. ICRISAT. Human Resource Development Programme. Patancheru, Andhra Pradesh 502 324, India.

Wambi. W., Tukamuhabwa, P., Puppala, N., Okello, S.D.K., Nalugo, R.G. and Kaaya, N.A. 2014. Narrow sense heritability and gene effects for late leaf spot resistance in valencia groundnuts. African Crop Science Journal 22:327-336

Zhang, Y., Kang, M.S. and Lamkey, K.R. 2005 DIALLEL-SAS05: A comprehensive programme for Griffing's and GardnerEberhart analyses. Agronomy Journal 97:1097-1106. 